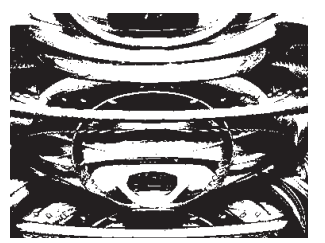

\title{
RISK PERCEPTION RELATED TO (IL)LICIT SUBSTANCE USE AND ATTITUDES TOWARDS ITS' USE AND LEGALIZATION - THE ROLE OF AGE, GENDER AND SUBSTANCE USE
}

Jelena MARIČIĆ, Ines SUČIĆ, Vlado ŠAKIĆ Institute of Social Sciences Ivo Pilar, Zagreb

UDK: 316.644:178

$316.644: 343.57$

Izvorni znanstveni rad

Primljeno: 27. 3. 2013.

The aim of this study was to determine the role of age, gender and tobacco, alcohol and marijuana use in relation to different aspects of attitudes toward (ill)licit substance use. Differences in risk perception and attitudes toward substance use were assessed between groups of active substance users, ex-substance users, and non-substance users with regard to their age and gender. Respondents generally associated moderate risk with using tobac$\mathrm{co} / \mathrm{alcohol} / \mathrm{marijuana}$ and large risk with using ecstasy/cocaine/ heroin, and they disapproved their use and legalization. Positive correlation was found between the consumption of different substances, and also between respondents' opinions on substance criminalization, perception of risk associated with substance use, and (il)licit substance use disapproval. Females and older respondents typically used (il)licit substances less and were more prone toward marijuana and heroin criminalization, substance use disapproval, and associated greater risk with substance use. Active users of any substance generally held the most permissive attitudes. The strongest effect of alcohol and tobacco use on attitudes was found among the youngest respondents, and the weakest among the oldest, which indicates the need for interventions to be focused even more on the younger population.

Keywords: risk perception, attitudes, tobacco, alcohol and marijuana use, active, ex and non-users 
Substance use can lead to risks on the physical, psychological, emotional and social levels, with various short and/or long term aversive consequences. From a medical perspective, risk is closely related to the nature, signs, symptoms and limitations arising out of the health conditions and its potential lethality, while from a broader perspective, risk can be associated with the adverse effects some behavior might have on somebody's family, job, and relationships (Sharma, 2011).

A number of knowledge-attitude-behavior change models has been developed to guide research and interventions related to substance use and other risky behaviors (Marcoux \& Shope, 1997). For example, the Precaution Adoption Process Model (Weinstein, 1999) deals with how people process risks and the relationship between risk perception and health protective behavior. Risk perception refers to individuals' beliefs about the likelihood of possible health problems in the future. Usually it is conceptualized in terms of personal vulnerability to the health effects of their risky behavior, optimistic bias (inaccurate estimation of lower personal risk in comparison to other counterparts) and precaution effectiveness (believing that engaging in precautionary behavior will be health beneficial) (Peretti-Watel, 2003).

Since health behavior models are mostly based on decision theories, risk behaviors are assumed to represent conscious actions. However, the relationship between risk perception and risky behavior is inconclusive. Meta-analysis by Harrison, Mullen, and Green (1992) showed that the average correlation between risk perception measures and health behaviors never exceeded 0.22 , and numerous longitudinal studies have even demonstrated the decline of risk perception among individuals who previously engaged in risky behaviors (for smoking relapse see Gibbons, Eggleston, \& Benthin, 1997; and for drinking behavior see Gerrard, Gibbons, Reis-Bergan, \& Russell, 2000). However, as Kotchick, Shaffer, Forehand, and Miller (2001) explained, knowledge that one is engaging in risky activities may lead to a heightened sense of personal risk (positive correlation), but at the same time, a reduced sense of vulnerability may contribute to greater risk taking (negative correlation).

\section{Social context}

Sharma (2011) emphasizes that cultural factors, socioeconomic status, and previous experiences shape health behaviours, including substance use. The evaluation attached to a particular pattern of substance use also varies over time and within culture (Room, 2005). Recent data on substance use among the general population in Croatia (Glavak Tkalić, Miletić, Ma- 
DRUŠ. ISTRAŽ. ZAGREB GOD. 22 (2013), BR. 4 STR. 579-599

MARIČIĆ, J., SUČIĆ, I., ŠAKIĆ, V.:

RISK PERCEPTION.. ričić, \& Wertag, 2012) showed that around one out of three adults is an active tobacco user (36.3\%), and 60.8\% reported alcohol consumption in the month preceding the survey. Also, $15.6 \%$ respondents reported ever taking cannabis at some point in their life. An individual's pattern of substance use is a matter of public health interest but also the subject of social evaluation in terms of (dis)approval in everyday life. The use may be closely associated with power, domination, positive values and statuses, could serve psychosocial adjustment and inclusion/exclusion in social groupings, may be derogated or stigmatized, or may be an expression of differences without specific implications (Room, 2005). Substance use and accompanied risks are influenced or governed by social institutions, since disapproval may be expressed in the form of state sanctions (Room, 2005). Social stakes attached to specific substance use, level of consumption and health problems are directly related to substances' availability and whether they are regular consumption items (e.g. fall/rise in the price and/ or taxes, imposed limits on the circumstances of sale). Till January 2013, in Croatia, possession of a narcotic drug for personal use (e.g. marijuana) was a criminal offence which envisaged a sentence in the form of a fine or up to 1-year of imprisonment (Criminal Code of the Republic of Croatia, 2011). The present legislation against tobacco and alcohol use is generally declarative. Buying and using tobacco and alcohol is prohibited to minors, but such behaviour by youth is generally tolerated in Croatian society. Also, the liberalisation of the border traffic regime as part of the integration process of Europe, as well as Croatia's tourist and maritime orientation, significantly affect the availability of all types of (il)licit substances in Croatia (Vugrinec et al., 2011).

\section{Sociodemographic correlates of risk perception and attitudes toward substance use}

Younger people more often rely on social comparison in risk estimation, perceive risk as smaller (Mravčík et al., 2005), and compared to their parents minimize the harm of periodic involvement in health-threatening activities (Cohn, Macfarlane, Yanez, \& Imai, 1995). Risk perception may change during maturation due to emergence of health problems which are more likely to appear at older age (Sharma, 2011), but also with changes in the individual's categorization of personal experiences into the temporal phase (Zimbardo \& Boyd, 1999). This time perspective provides the framework to select and pursue short and long-term goals, and we could distinguish between five time perspective dimensions: past-negative, past-positive, present-hedonistic, present-fatalistic and future (Zimbardo \& Boyd, 
DRUŠ. ISTRAŽ. ZAGREB GOD. 22 (2013), BR. 4, STR. 579-599

MARIČIĆ, J., SUČIĆ, I. ŠAKIĆ, V.:
RISK PERCEPTION...

1999). Negative correlation was found between age and the present-hedonistic dimension (Hamilton, Kives, Micevski, \& Grace, 2003), while positive between age and the present-fatalistic dimension (D'Alessio, Guarino, De Pascalis, \& Zimbardo, 2003).

Public opinion researchers have found that being male (Trevino \& Richard, 2002), younger and more educated has been associated with positive attitudes towards marijuana legalization (Saieva, 2008), and risks generally tend to be judged as lower by men than by women (e.g., Flynn, Slovic, \& Mertz, 1994; Gutteling \& Wiegman, 1993; Mravčík et al., 2005) including risk associated with tobacco, alcohol, tranquilizers, and inhalants use (Bejarano et al., 2011; Spigner, Hawkins, \& Loren, 1993). Gender differences in risk perception could be at least partially attributed to gender socialization (Davidson \& Freudenburg, 1996), the fact that women have less power and control (Finucane, Slovic, Mertz, Flynn, \& Satterfield, 2000), but also to differences in the time perspective since women are more prone to the present-fatalistic perspective (D'Alessio et al., 2003), past-positive perspective (Zimbardo \& Boyd, 1999) and to the future perspective and less prone to the present-hedonistic perspective (Keough, Zimbardo, \& Boyd, 1999; Zimbardo, Keough, \& Boyd, 1997).

\section{Attitudes, risk perception and (il)licit substance use}

Individual experience with substance use is viewed as one of the principal factors affecting actual use. In Stacy, Bentler, and Flay's (1994) research past behaviour predicted attitudes concerning smoking, but not concerning alcohol or marijuana use. In contrast, attitudes predicted alcohol use and marijuana use, but not smoking behaviour. Also, while Kahle and Berman (1979) and Bentler and Speckart (1979) found support for attitudes predicting alcohol consumption, Johnson (1988) found no such evidence. The time perspective also moderated the link between marijuana use and risk perceptions (Apostolidis, Fieulaine, Simonin, \& Rolland, 2006), and for example, the present-hedonistic dimension was positively associated with substance use (Keough et al., 1999), while future orientation was positively correlated with health responsibility (Hamilton et al., 2003) and negatively with substance use (Keough et al., 1999).

Findings concerning disparities between risk perception and avoidance of risky behavior are often reported for tobacco use (e.g., Sutton, 1999; Weinstein, 2003). Park et al. (2009) found that perception of personal risk of diseases related to smoking was curvilinear among tobacco users and associated with intentions to quit smoking. Both current and former smokers overestimated lung cancer prevalence among smokers, and underestimated other risks of smoking. This tendency 
DRUŠ. ISTRAŽ. ZAGREB GOD. 22 (2013), BR. 4 STR. 579-599

MARIČIĆ, J., SUČIĆ, I. ŠAKIĆ, V.: RISK PERCEPTION.. was more emphasized in current smokers. In Jenks' study (1992) smokers who mostly denied the health risks did not differ statistically from the non- or former smokers, although they did express the least satisfaction with health and life in general. Active smokers in comparison to non-smokers and former smokers more likely agreed that smoking is a dirty habit, both psychologically and physically addictive, and that it will lead to major health problems, while former smokers were least likely to agree that it is physically and psychologically addictive.

Among adolescents, experience with alcohol use had a negative correlation with risk perception about becoming an alcoholic (Lundborg \& Lindgren, 2002). Also, adult persons who consumed larger quantities of alcohol felt there was significantly less risk associated with alcohol use than did respondents who consumed smaller quantities of alcohol (Borrelli, Hayes, Dunsiger, \& Fava, 2010).

A study carried out among secondary school students (Bejarano et al., 2011) revealed lower risk of drug use among individuals that attributed at least moderate risk to drug use as compared to those adolescents who responded that they did not know the risk or perceived drug use as low risk. According to Lejčková and Csémy (2005), adolescents who do not use any drugs tend to view drug use as carrying a high risk, disapprove its use, and see the availability of drugs as restricted. With the more severe substance use those attitudes gradually change, and regular users of illicit substance were the most liberal and tolerant to drug use, consider illicit substances easily available and relatively harmless. In other research, users of all illicit substances, as well as users of marijuana only, were more likely to support the legalization of marijuana (Trevino \& Richard, 2002) and less disapproved use of any illicit drugs including cannabis than non-drug users (Peretti-Watel, 2003), but none of the users' groups were more or less likely to support the legalization of cocaine or heroin (Trevino \& Richard, 2002). Peretti-Watel (2003) also found that the more the respondents used cannabis, the more they emphasized the risk induced by illicit drugs, except for cannabis.

It seems that actual substance use changes the perception of social stakes and risk related to the use of specific substance (Peretti-Watel, 2003), even though alcoholism and drug addiction are generally socially disapproved or stigmatized (Room, 2005). Association between attitudes toward drug use, risk perception and actual (il)licit substance use is an interesting area of research, since attitudes and risk perception could serve as facilitators as well as inhibitors of consuming behavior. That association is affected by some basic human needs (e.g., self-esteem, a sense of security, pleasure and excitement) and by different environmental and social influences (e.g., 
DRUŠ. ISTRAŽ. ZAGREB GOD. 22 (2013), BR. 4, STR. 579-599

MARIČIĆ, J., SUČIĆ, I. ŠAKIĆ, V.:

RISK PERCEPTION. social norms and legislations, health expectancies, personal level of stakes in conformity). Also, the importance of attitudes and perceived risks could vary with regard to sociodemographic characteristics but also with regard to current behavior (e.g., substance use). Because of the widespread use and potential of attitudes and risk concepts in health-behavior research and interventions, it is necessary to better understand these concepts and to document their predictive impact on health prohibiting and/or harmful behavior.

\section{THE PRESENT STUDY}

The study attempts to understand how people perceive risks related to substance use and to investigate the role of perceived risk and attitudes toward substance use as behavioral determinants. Specifically, the present study wants to assess whether opinions about drug policies and about trying (il)licit substances as well as perception of risk associated with substance use are related to actual (il)licit substance use and sociodemographic variables. Thus, differences in risk perception and attitudes toward substance use are assessed between groups of active, ex and non-users of tobacco, alcohol and marijuana.

\section{METHOD}

\section{Participants}

(1) TABLE 1

Subsamples' demographics

The data was gathered from the 4756 respondents aged 15-64 $\left(\right.$ Mage $=39.8, S D_{\text {age }}=14.58,56 \%$ women, response rate $\left.53.1 \%\right)$ of the general population in the Republic of Croatia, representing the multistage stratified sample of residents living in private households chosen by random choice of units within strata.

Data analyses for the purpose of this study were performed on three subsamples with regard to the level of tobacco, alcohol and marijuana use (Table 1).

\begin{tabular}{|c|c|c|c|c|c|}
\hline \multirow{2}{*}{\multicolumn{2}{|c|}{ Category of substance use }} & \multirow[b]{2}{*}{$\mathrm{n}$} & \multicolumn{3}{|c|}{ Age } \\
\hline & & & $M$ & $\overline{S D}$ & $\%$ males \\
\hline \multirow[t]{3}{*}{ Active users } & tobacco & 1642 & 38.22 & 13.278 & 48.9 \\
\hline & alcohol & 479 & 43.82 & 14.223 & 73.8 \\
\hline & marijuana & 70 & 27.32 & 9.145 & 73.9 \\
\hline \multirow[t]{3}{*}{ Ex-users } & tobacco & 846 & 44.34 & 12.732 & 49.3 \\
\hline & alcohol & 711 & 45.34 & 13.863 & 33.4 \\
\hline & marijuana & 51 & 30.40 & 7.222 & 80.4 \\
\hline \multirow[t]{3}{*}{ Non-users } & tobacco & 2077 & 40.01 & 15.453 & 37.8 \\
\hline & alcohol & 674 & 42.38 & 15.583 & 22.4 \\
\hline & marijuana & $93^{1}$ & 40.61 & 12.287 & 46.2 \\
\hline
\end{tabular}




\section{Procedure}

The data was gathered by face-to-face interviews using paper-pencil format questionnaire. Confidentiality and anonymity of the data gathered was assured, as well as parental consent for interviewing the minors.

\section{Measures and variables}

The data were collected in 2012 as a part of the project Substance abuse among the general population of the Republic of Croatia (Glavak Tkalić et al., 2012), using the European Model Questionnaire (EMCDDA, 2002), which represents the standard instrument for national surveys on substance use.

\section{Behavioral measures}

Tobacco use was computed as a composite, based on three items: "Did you ever smoke?" (yes/no), "Did you smoke in the last 12 months?" (yes/no), and "On average, how many cigarettes did you smoke in the last 30 days?" (do not smoke every day/up to 5 cigarettes/5-10/10-20/20-30/30-40/more than 40 cigarettes), and respondents were divided into three categories of tobacco users: active - use tobacco every day, ex - used tobacco before but not in the last 12 months, and non-users - never used tobacco.

Alcohol use was computed as a composite, based on the following items: "How old were you when you drank alcohol for the first time?" ( years/ I never drank alcohol), "Did you drink alcohol in the last 12 months?" (yes/no), and "If you drink alcohol every day, how old were when you started drinking alcohol on a daily basis?" (_ _ years/ I do not drink any alcoholic beverage on a daily basis), and respondents were divided into three categories of alcohol users: active - drank at least one alcoholic beverage every day, ex - used alcohol before but not in the last 12 months, and non-users - never used alcohol.

Marijuana $u e^{2}$ was computed as a composite, based on several items: "Did you ever use marijuana?" (yes/no), "Did you use marijuana in the last 12 months?" (yes/no), "Did you use marijuana in the last 30 days?" (yes/no), "Did you ever use marijuana regularly?" (yes/no), and respondents were divided into three categories of marijuana users: active - used marijuana regularly and used it in the last 30 days, ex - used marijuana regularly but not in the last 12 months and non-users never used marijuana.

\section{Attitudes}

Opinions about substance legalization/criminalization. Respondents were asked to rate their opinion about allowing people to take marijuana and about allowing people to take heroin using a 5 -point scale ( 1 - not at all agree, 5 - completely agree). After 
DRUŠ. ISTRAŽ. ZAGREB GOD. 22 (2013), BR. 4, STR. 579-599

MARIČIĆ, J., SUČIĆ, I., ŠAKIĆ, V.:

RISK PERCEPTION..
(1) TABLE 2

Description of the attitudes' measures reverse scoring, a higher score indicated favoring substance criminalization.

(Il)licit substance use disapproval. Respondents on a 3-point scale ( 1 - do not disapprove, 2 - disapprove, 3 - strongly disapprove) estimated their degree of disapproval of people trying ecstasy once or twice, trying heroin once or twice, smoking 10 or more cigarettes a day, drinking one or two drinks several times a week, and occasionally smoking marijuana. Principal component analysis (PCA) for the overall sample was performed in order to attain one overall indicator of the (i) licit substance use disapproval. ${ }^{3}$ It was computed as the sum of responses to the respective items divided by the number of items included, with higher score indicating higher disapproval (Table 2).

Perception of risk associated with (il)licit substance use was measured through questions concerning respondents' perception of risk of other people harming themselves (physically or in other ways) if they smoke one or more packs of cigarettes a day, have five or more alcoholic drinks each weekend, smoke marijuana regularly, try ecstasy once or twice, try cocaine (or crack) once or twice, or try heroin once or twice. Respondents estimated the level of risk for each of the substance use on a four point scale ( 1 - no risk, 4 - big risk). After performing PCA with varimax rotation for the overall sample, two factors were extracted, the first explaining $49.7 \%$, and the second $23.8 \%$ of variance. Three items (trying cocaine, heroin and ecstasy) loaded highly on the first factor (ranging from 0.859 to 0.935 ), and being indicator of risk, associated with the perceived use of illicit and more severe substances, while the other three items (trying alcohol, tobacco and marijuana) loaded highly on the second factor, (ranging from 0.648 to 0.847 ) and thus being indicator of perceived risk, associated with the use of light and less prohibited substances.

\begin{tabular}{lrrrrrr}
\hline Variables & $\mathrm{N}$ & nitems & Scale range & $M$ & $S D$ & $\alpha$ \\
\hline Criminalization of marijuana & 4828 & 1 & $1-5$ & 3.96 & 1.349 & n/a \\
Criminalization of heroin & 4826 & 1 & $1-5$ & 4.79 & 0.666 & n/a \\
(II)licit substance use disapproval & 4023 & 4 & $1-3$ & 2.23 & 0.549 & 0.712 \\
Risk taking - tobacco/alcohol/marijuana & 4784 & 3 & $1-5$ & 3.38 & 0.633 & 0.702 \\
Risk taking - ecstasy/cocaine/heroin & 4794 & 3 & $1-5$ & 3.78 & 0.506 & 0.881 \\
\hline
\end{tabular}

\section{Sociodemographic variables}

Respondents' gender and age were taken into account since they were usually significantly related to (il)licit substance use and to attitudes toward its use, as well as perception of risk associated with (il)licit substance use (e.g., Apostolidis et al., 2006; Roberts, 2012). 
According to the data in Table 3, it can be concluded that being female was related to a lower use of (il)licit substance and greater marijuana and heroin criminalization, (il)licit substance use disapproval, and estimation of greater risk with substance use. The same trend in results held for the older respondents, with the exception of alcohol consumption, since alcohol consumption was not significantly related to the respondents' age. Overall, there was a significant positive relationship between the use of different substances, and people who were active users of one (il)licit substance were also more likely to be active users of another (il)licit substance. There was also a significant positive relationship between respondents' opinions on substance criminalization, perception of risk associated with substance use, and (il)licit substance use disapproval. Moreover, substance use was statistically significantly negatively related to respondents' opinions on substance criminalization, 4 perception of risk associated with substance use and (il)licit substance use disapproval (for more details see Table 3).

Multivariate Analyses of Variance (MANOVA) were performed in order to examine the differences in risk perception related to (il)licit substance use and attitudes towards its use and legalization with regard to the level of substance use. Three separate analyses were conducted for the tobacco, alcohol, and marijuana use, and in each of the analyses gender and age were added as additional factors (Table 4).

For attitudes concerning tobacco use, overall MANOVA revealed a significant main effect of tobacco use, age, and gender, as well as the interaction of age and gender, tobacco use and age, and interaction of tobacco use, age, and gender (Table 4). Active, ex, and non-tobacco users significantly differed in their attitudes toward marijuana criminalization $(F(2,3694)=54.81$, $\mathrm{p}<0.0001)$, (il)licit substance use disapproval $(F(2,3694)=102.70$, $\mathrm{p}<0.0001)$, and perception of risk associated with tobacco/alcohol/and marijuana use $(F(2,3694)=129.33, \mathrm{p}<0.0001)$ (Figure 1). Active tobacco users perceived lower risk associated with ecstasy/cocaine/heroin use than non-tobacco and ex-tobacco users $(F(2,3694)=26.72, \mathrm{p}<0.0001)$. There were also significant differences among all age groups in attitudes toward marijuana criminalization $(F(2,3694)=150.19, \mathrm{p}<0.0001)$, (il)licit substance use disapproval $(F(2,3694)=141.74, \mathrm{p}<0.0001)$, and perception of risk associated with all substance use $(F(2,3694)=76.96$, $\mathrm{p}<0.0001 ; F(2,3694)=71.60, \mathrm{p}<0.0001)$. In attitudes toward heroin legalization, a significant difference was found only between the youngest and the oldest groups of respondents $(F(2,3694)=6.039, \mathrm{p}=0.002)$. 
DRUŠ. ISTRAŽ. ZAGREB GOD. 22 (2013), BR. 4, STR. 579-599

MARIČIĆ, J., SUČIĆ, I. SAKIC, V.:
RISK PERCEPTION...

- TABLE 3

Correlation 5 among study variables

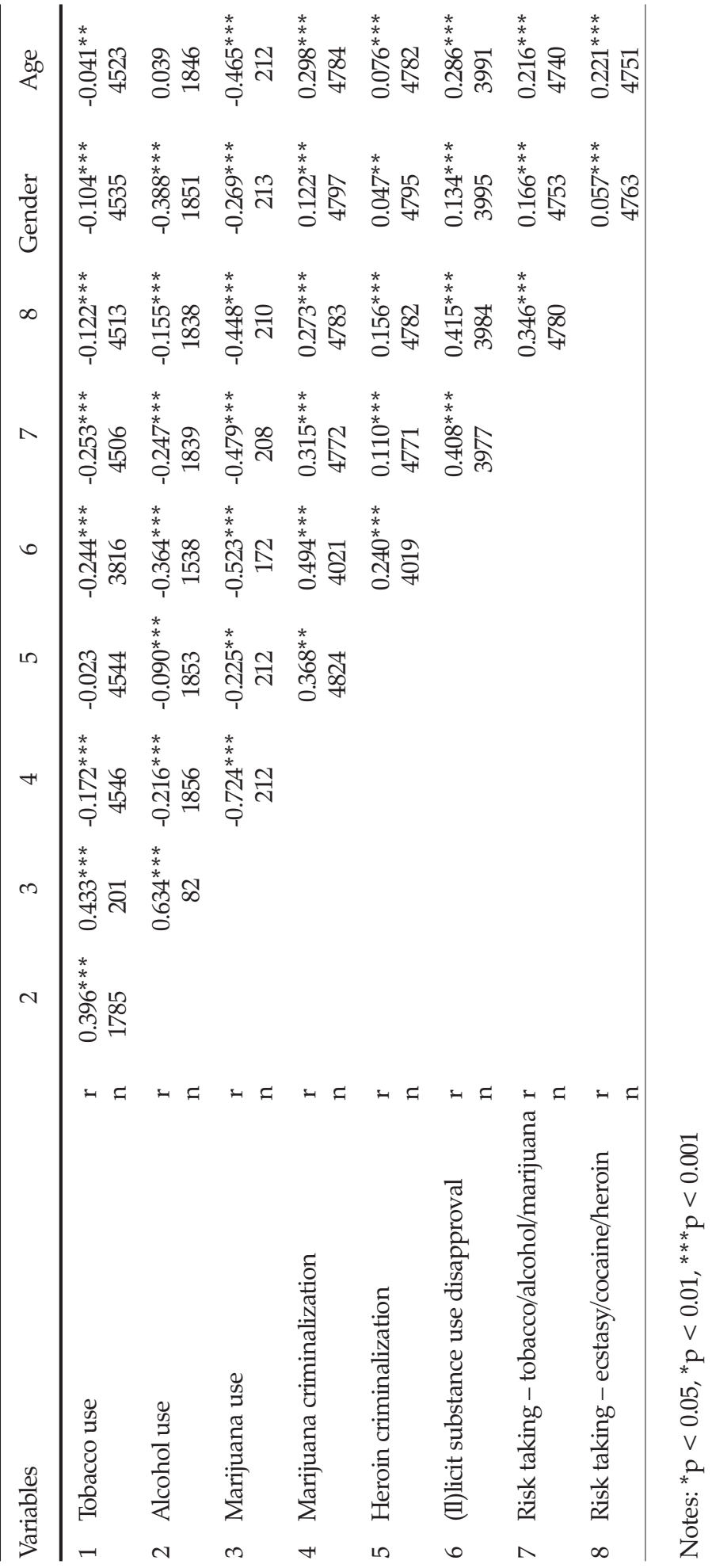




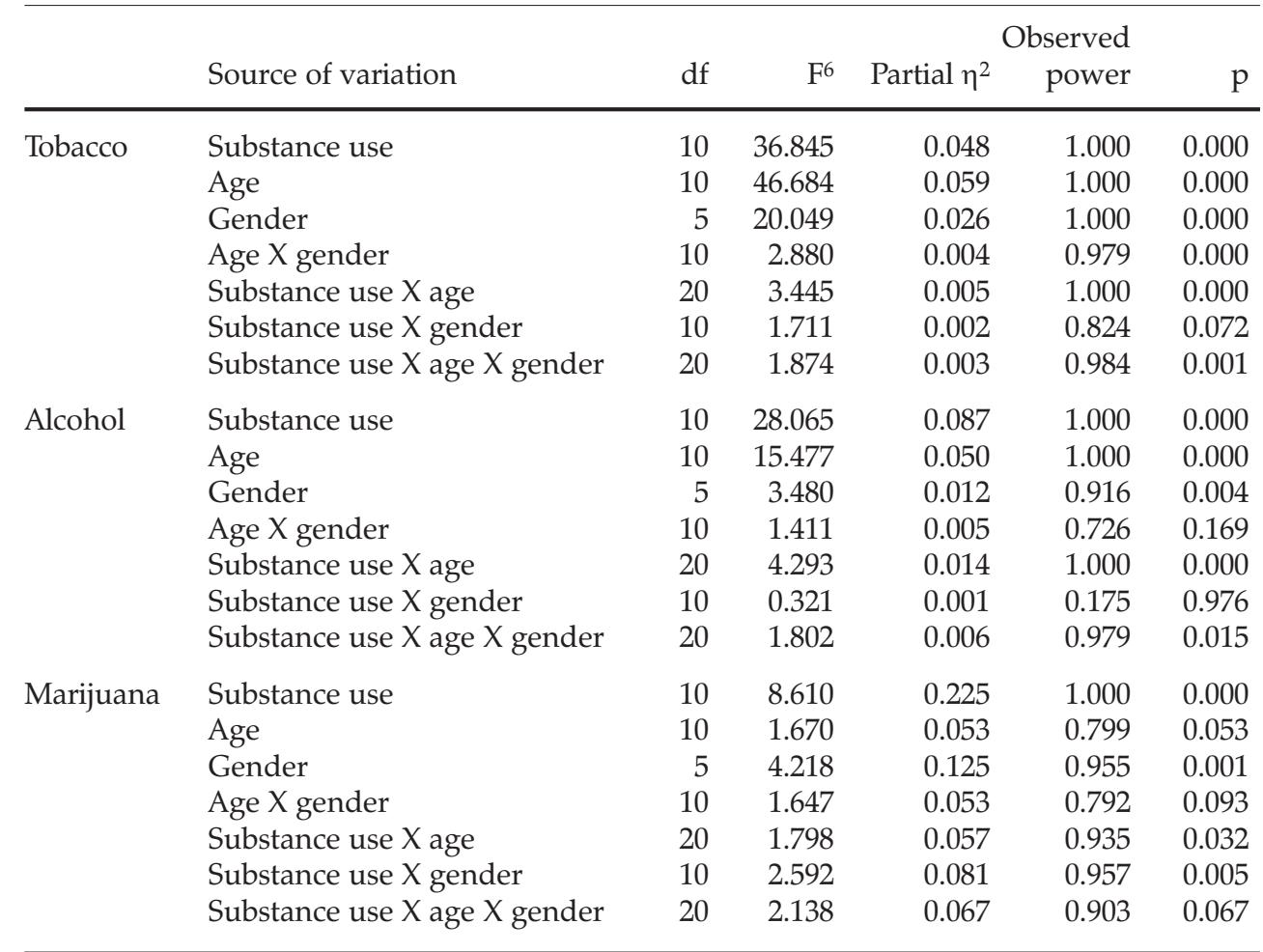

(1) TABLE 4

Overall results of MANOVA
As to the main effect of gender, females' attitudes toward marijuana criminalization $(F(1,3694)=40.94, \mathrm{p}<0.0001)$, (il)licit substance use disapproval $(F(1,3694)=22.92, p<0.0001)$, and perception of risk associated with tobacco/alcohol/marijuana use $(F(1,3694)=77.42$, $p<0.0001)$, were significantly less permissive than males' attitudes. The strongest effect of tobacco use on the attitudes toward marijuana criminalization $(F(4,3694)=7.21, \mathrm{p}<0.0001)$, (il)licit substance use disapproval $(F(4,3694)=5.91, \mathrm{p}<0.0001)$, and perception of risk associated with all substance use $(F(4,3694)=4.17, \mathrm{p}=0.002$; $F(4,3694)=4.07, \mathrm{p}=0.003)$ was found among the group of youngest respondents, and the weakest among the group of oldest respondents.

For attitudes concerning alcohol use, MANOVA revealed a significant main effect of alcohol use, age, and gender, as well as interaction of alcohol use and age, and interaction of alcohol use, age and gender (Table 4). Active, ex, and non-alcohol users significantly differed in their (il)licit substance use disapproval $(F(2,1471)=97.02, \mathrm{p}<0.0001)$. Active alcohol users held more permissive attitudes toward marijuana $(F(2,1471)=70.48$, $\mathrm{p}<0.0001)$ and heroin legalization $(F(2,1471)=12.56, \mathrm{p}<0.0001)$, and associated less risk with (il)licit substance use $(F(2,1471)=$ $71.07, \mathrm{p}<0.0001 ; F(2,1471)=33.40, \mathrm{p}<0.0001)$ than non-alcohol and ex-alcohol users (see Figure 1). There were also sig- 
DRUŠ. ISTRAŽ. ZAGREB GOD. 22 (2013), BR. 4, STR. 579-599

MARIČIĆ, J., SUČIĆ, I., ŠAKIĆ, V.:

RISK PERCEPTION..

(1) FIGURE 1

Risk perception and attitudes toward

substance use among categories of substance users nificant differences among all age groups in attitudes toward marijuana criminalization $(F(2,1471)=47.68$, p $<0.0001)$, (il)licit substance use disapproval $(F(2,1471)=27.70, \mathrm{p}<0.0001)$, and perception of risk associated with all substance use $(F(2,1471)=$ 32.03, $\mathrm{p}<0.0001 ; F(2,1471)=29.17$, $\mathrm{p}<0.0001)$. Females' attitudes toward marijuana criminalization were significantly less permissive than males' attitudes $(F(1,1471)=11.99, \mathrm{p}<0.0001)$. Also, the strongest effect of alcohol use on the attitudes toward marijuana criminalization $(F(4,1471)=14.09$, $\mathrm{p}<0.0001)$, and perception of risk associated with all substance use $(F(4,1471)=$ $5.08, \mathrm{p}<0.0001 ; F(4,1471)=8.72$, $\mathrm{p}<0.0001)$ was found among the group of youngest respondents, and the weakest among the group of oldest respondents.

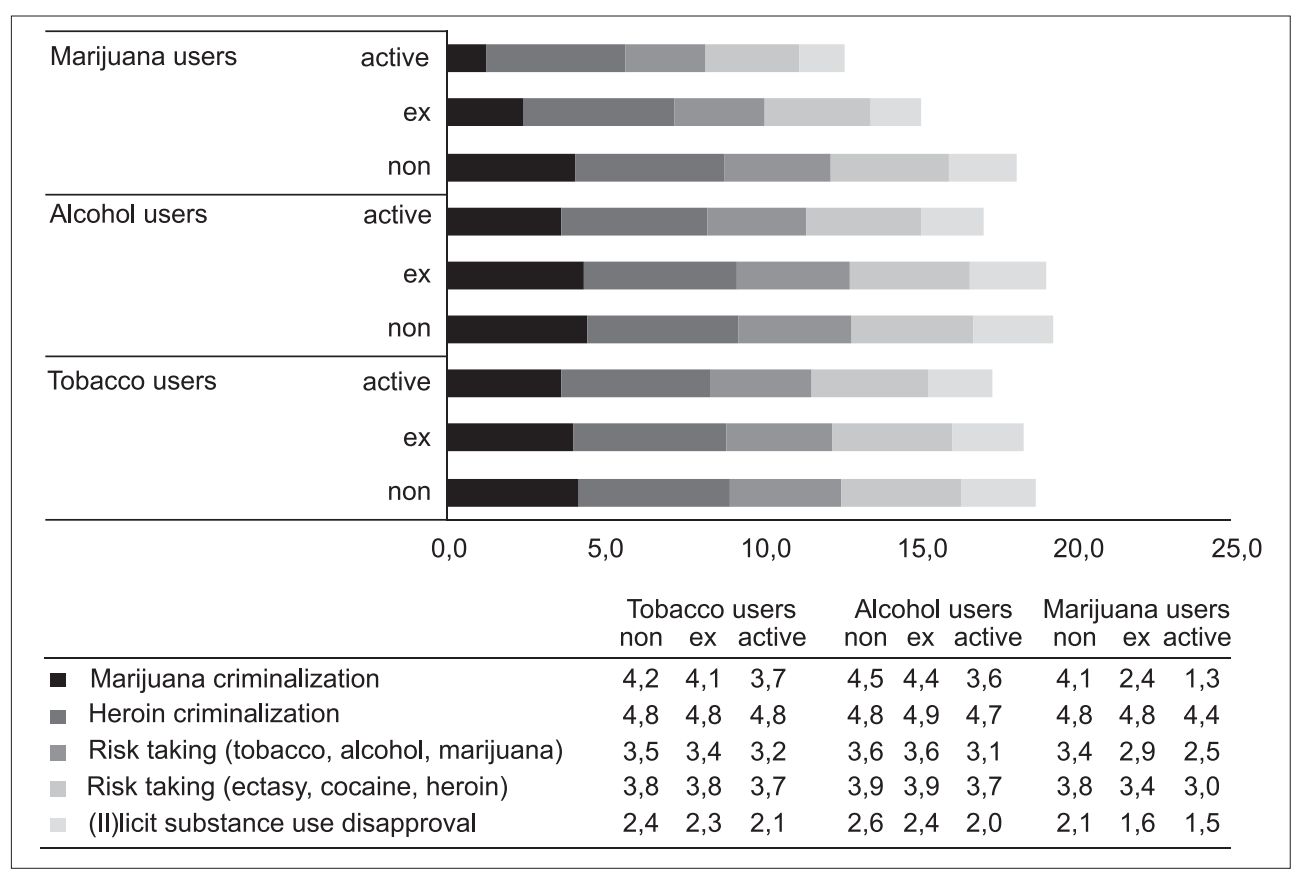

For attitudes concerning marijuana use, MANOVA revealed a significant main effect of marijuana use, and gender, and interaction of marijuana use and gender, and marijuana use and age (Table 4). Active, ex, and non-marijuana users significantly differed in their attitudes toward marijuana criminalization $(F(2,166)=29.26, \mathrm{p}<0.0001)$. Active marijuana users disapproved (il)licit substance use less $(F(2,166)=24.12$, $\mathrm{p}<0.0001)$, and perceived lower risk associated with ecstasy/ cocaine/heroin use $(F(2,166)=17.12, \mathrm{p}<0.0001)$, than nonand ex-marijuana users (see Figure 1). As to the main effect of gender, females' attitudes toward marijuana criminalization $(F(1,166)=8.48, \mathrm{p}=0.004)$, and perception of risk associated with ecstasy/cocaine/heroin use $(F(1,166)=7.27, \mathrm{p}=0.008)$ were significantly less permissive than males' attitudes. A stronger 
effect of marijuana use on the (il)licit substance use disapproval was found among females than males $(F(2,166)=7.19$, $\mathrm{p}=0.001)$

Two-thirds of the respondents in this study agreed that people should not be permitted to take marijuana and almost all agreed that people should not be permitted to take heroin. On average, respondents associated moderate risk with using tobacco/alcohol/marijuana, and large risk with using ecstasy/ cocaine/heroin. Moreover, they disapproved occasional (il)licit substance use. Similarly, roughly one third of Americans support general legalization of marijuana, while about half believe that marijuana possession should remain classified as a criminal offense (Gallup, 2005). Also, 90\% of the respondents opposed the legalization of cocaine and heroin (MacCoun, Kahanm, \& Gillespie, 1993).

As expected, respondents who were active users of one (il)licit substance were also more likely to be active users of another (il)licit substance. The largest proportion of the respondents in this survey concurrently used alcohol and tobacco in the past month $(48.7 \%)$, and around a quarter $(25.7 \%)$ used alcohol and tobacco in the month prior to the survey and also used marijuana at least once during their life-time. The tendencies toward different risky behaviors are often correlated, and Jenks (1992) found that smokers are more likely to see themselves as persons prone to risk and drinking of alcoholic beverages and less inclined to use seat belts in the car and eat a healthy diet (see also Berg, Schauer, Rodgers, \& Narula, 2012). This is not surprising since persons using one substance or participating in other risky behaviours are probably less concerned about their health or social disapproval than persons not using any substances or who have high stakes in conformity. Consequently, sole substance users will probably attach lower social stakes or risk to other forms of risky behaviour or to the use of another substance.

In this study, but also in previous research (Saieva, 2008; Trevino \& Richard, 2002), attitudes toward marijuana and heroin legalization as well as perceived risk associated with (il)licit substance use proved to be related to respondents' sociodemographic characteristics as well as the level of substance use. In general, in this study, being female and of older age was related to lower use of (il)licit substance and greater support for marijuana and heroin criminalization, stronger (il)licit substance use disapproval, and estimation of greater risk associated with substance use.

Based on the correlations and differences between age groups, it could be concluded that with older age attitudes toward substance use, (il)licit substance policies, and risk perception are becoming more stringent. Risk perception may 
DRUŠ. ISTRAŽ. ZAGREB GOD. 22 (2013), BR. 4, STR. 579-599

MARIČIĆ, J., SUČIĆ, I., ŠAKIĆ, V.: RISK PERCEPTION.. increase with maturation due to a decrease in sensation seeking and decline in danger invulnerability (Ravert et al., 2009), due to greater exposure to health problems, lower optimism about avoiding harm and misfortune (Cohn et al., 1995), and a higher sense of health responsibility related to the change from the present-hedonistic perspective toward a more future orientation (Keough et al., 1999). The tendency of young people to advocate drug use (especially cannabis) is frequently found (Saieva, 2008; Trevino \& Richard, 2002) and the observed trends in marijuana use with regard to age may correlate with a similar pattern of attitudes toward its use and legalization (Saieva, 2008). For example, while the average age of active marijuana users in the current study was 27 , the average age of ex-marijuana users was 31. Since marijuana use appears to be typically short and declines relatively steeply and early with age (usually by 40 s, see Kerr, Greenfield, Bond, Ye, \& Rehm, 2007; Lynskey et al., 2006), the respondents are also showing less favoring attitudes toward its legalization as they are getting older. Also, people may diminish their support for marijuana legalization later in life, in part, because they become more conservative (Brown, Glaser, Waxer, \& Geis, 1974), but also because by getting older, the social stakes of marijuana use are becoming higher.

As to the main effects of gender, females' attitudes toward marijuana criminalization were significantly less permissive than males' attitudes, and the perception of risk associated with substance use was greater. As a result of gender differences in substance use patterns (women in this study were far less represented among groups of active-substance users, and more represented among groups of non-substance users, see also Lynskey et al., 2006), traditional social roles and more conforming behavior, as well as cultural "acceptance" of males consuming substances more than females (Borrelli et al., 2010), a difference in attitudes towards substance use and risk perceptions by gender was expected. Gender differences in risk perception could also be connected with women being more aware of the health warnings associated with (il)licit substance use in the first place (Mazis, Morris, \& Swasy, 1991), and differences in the time perspective (Keough et al., 1999; Zimbardo \& Boyd, 1999).

The statistically significant negative association between the respondents' actual substance use and opinions on substance criminalization, perception of risk associated with substance use and (il)licit substance use disapproval are in accordance with the prediction that risk perception is negatively correlated with risk-taking behavior. The higher the perceived risk of a behavior, the lower the tendency to engage in that behavior (Reyna \& Lloyd, 2006), and perceived risk serves as 
DRUŠ. ISTRAŽ. ZAGREB GOD. 22 (2013), BR. 4 STR. 579-599

MARIČIĆ, J., SUČIĆ, I. ŠAKIĆ, V.: RISK PERCEPTION.. a protective factor. Differences among groups of active, ex, and non-substance users found in this study also confirmed this prediction, as well as various previous studies (Bejarano et al., 2011; Borrelli et al., 2010; Jenks, 1992; Lejčková \& Csémy, 2005; Lundborg \& Lindgren, 2002). It is interesting that in this study, the perception of lower risk among active users was not limited to the perception of risk associated with the substance in question, but extended to the use of other illicit drugs regardless of the type of substance used. Thus, each substance use cannot be considered outside its symbolic or real relationship with the other substances, and without taking into the consideration the overlap of stakes between them. Also, attitudes toward drug criminalization, (il)licit substance use disapproval and perceived risk were quite similar between groups of former users and non-users for alcohol and marijuana as well. These results are not surprising since changes in the prevalence of different health behaviors are often not correlated with changes in risk awareness (Steptoe et al., 2002) due to unrealistic optimism, scapegoating of habitual users, and comparison or risks attached to different substances (Peretti-Watel, 2003). Ex-substance users sometimes even perceive lower level of risk associated with using those substances than non-users (Gerrard et al., 2000; Gibbons et al., 1997).

In general, the strongest effect of tobacco and alcohol use on the attitudes toward marijuana criminalization, and perception of risk associated with all substance use, was found among the group of youngest respondents, and the weakest among the group of oldest respondents. Since younger age and active substance use were constantly found to be related to the most liberal and tolerant attitudes to drug use and perception of (il)licit substances as relatively harmless, those variables represent the most powerful risk factors for habitual substance abuse. A stronger effect of marijuana use on the (il)licit substance use disapproval was found among females than among males. It is interesting that men who are active and ex-marijuana users disapprove (il)licit substance use more than women in those categories, while men who do not use marijuana disapprove (il)licit substance use less than women non-marijuana users. Men are still more likely than women to smoke marijuana for a prolonged duration during their lifetime (Lynskey et al., 2006), and they may be socialized in different ways, so that the influences of marijuana acceptance appear more readily in the social lives of males than in females (Rienzi et al., 1996). Other studies indicated some additional gender differences that must be considered in understanding attitudes towards illicit drugs, such as that women were more likely to attribute habitual use of substance to biological or environmental factors, to perceive drugs as more 
DRUŠ. ISTRAŽ. ZAGREB GOD. 22 (2013), BR. 4, STR. 579-599

MARIČIĆ, J., SUČIĆ, I. ŠAKIĆ, V.:

RISK PERCEPTION. powerful and a higher incidence of substance abuse, and to believe prevention and treatment were more effective (Kauffman, Silver, \& Poulin, 1997).

Thus, since the use of one (il)licit substance is a gateway to the use of another (il)licit substance, primary prevention needs to cover a wide range of (il)licit substances. Also, prevention and effective treatment interventions should be even more focused on males, and young people, and be knowledge-based and implemented directly into their primary environment in which they make their decisions about substance use. Comprehensive public health measures and anti-substance use campaigns followed by consistent restrictions on substance use, and better law enforcement would certainly contribute to more efficient prevention.

\section{Study strengths and limitations}

Several study limitations were related to the use of the questionnaire: ambiguous terms used to capture substance use severity (e.g., regularly), possibility of selection bias, lack of a uniform measure of different substance use, and social desirability of the answers, especially about illicit substance use. Also, since respondents were asked to state their perception of the general risk associated with (il)licit substance use, it remains unanswered if respondents would assess the same likelihood of risk to themselves as for others. Moreover, the obtained results deserve a certain reservation, since due to a large sample size, small size effects were significant, and the household-based sample is not a good frame for studying the marginalized and socially excluded groups. Thus, future studies should tackle this problem by combining different research methods, and also capture specific personal risks related to substance use (e.g., disease/injuries, breakdown of relationships, exclusion from important social groupings, loss of status, power) important in a decision-making context.

Despite its restrictions, cross-national administration of the questionnaire helped increase the generalizability of these study findings. Also, understanding how people perceive the risks associated with their substance use is important in order to design the most effective interventions to decrease unsafe substance use, but only a few previous research studies have focused on how active users, non-users and ex-users perceive the risks associated with substance use, and almost no research focused on perceptions of the risk among users of different substances. Since risk perception and attitudes are not necessarily the same and equally prominent among all sociodemographic categories, taking into account the respondents' age and gender was definitely an additional strength of this study, although in future studies other important personal characteristics should also be taken into account. 
${ }^{1}$ Due to large differences in sample sizes between active users $(n=70)$, ex-users $(n=51)$ and non-users of marijuana $(n=4077)$, for the purposes of this study a random sample of $2 \%$ of marijuana non-users is selected for further analyses.

2 The measure of marijuana use was used in this study since marijuana was the most commonly used illicit drug (15.6\% of respondents reported having ever used it in their lifetime), and the lifetime prevalence rates of taking other individual types of drugs were considerably lower (below 3\%), and were as follows: amphetamines $2.6 \%$, ecstasy $2.5 \%$, cocaine $2.3 \%$, LSD $1.4 \%$, and heroin $0.4 \%$.

3 Since the item smoking 10 or more cigarettes a day loaded on the second factor (0.957) was mainly insignificantly related to the other items (from 0.021 to 0.032 ), and its exclusion from the scale resulted in the improvement of Cronbach's Alpha, the item was excluded from the scale.

4 An exception is the non-significant association between tobacco use and attitudes toward heroin criminalization $(\mathrm{r}(4545)=-0.023, \mathrm{p}=0.114)$. Caution is needed in the interpretation of this association since a large sample size resulted in low correlations (e.g. 0.041) being statistically significant.

5 Spearman's rho

6 Pillai's Trace

\section{REFERENCES}

Apostolidis, T., Fieulaine, N., Simonin, L., \& Rolland, G. (2006). Cannabis use, time perspective and risk perception: Evidence of a moderating effect. Psychology $\mathcal{E}$ Health, 21(5), 571-592. doi:10.1080/1476832 0500422683

Bejarano, J., Ahumada, G., Sa'nchez, G., Cadenas, N., de Marco, M., Hynes, M., \& Cumsille, F. (2011). Perception of risk and drug use: An exploratory analysis of explanatory factors in six Latin American countries. The Journal of International Drug, Alcohol and Tobacco Research, 1(1), 9-17.

Bentler, P. M., \& Speckart, G. (1979). Models of attitude-behavior relations. Psychological Review, 86(5), 452-464. doi:10.1037/0033-295X .86.5.452

Berg, C. J., Schauer, G. L., Rodgers, K., \& Narula, S. K. (2012). College student smokers: Former versus current and nonsmokers. American Journal of Preventive Medicine, 43(5), 229-236. doi:10.1016/j.amepre. 2012.07.038

Borrelli, B., Hayes, R. B., Dunsiger, S., \& Fava, J. L. (2010). Risk perception and smoking behavior in medically ill smokers: A prospective study. Addiction, 105(6), 1100-1108. doi:10.1111/j.1360-0443.2010. 02900.x

Brown, J. W., Glaser, D., Waxer, E., \& Geis, G. (1974). Turning off: Cessation of marijuana use after college. Social Problems, 21(4), 527-538. doi: $10.2307 / 799990$ 
DRUŠ. ISTRAŽ. ZAGREB GOD. 22 (2013), BR. 4, STR. 579-599

MARIČIĆ, J., SUČIĆ, I., ŠAKIĆ, V.:

RISK PERCEPTION.
Cohn, L. D., Macfarlane, S., Yanez, C., \& Imai, W. K. (1995). Risk-perception: Differences between adolescents and adults. Health Psychology, 14(3), 217-222. doi:10.1037//0278-6133.14.3.217

Criminal Code of the Republic Croatia (OG, 125/2011)

Davidson, D., \& Freudenburg, W. (1996). Gender and environmental risk concerns. Environment $\mathcal{E}$ Behavior, 28(3), 302-339. doi:10.1177/001 3916596283003

D'Alessio, M., Guarino, A., De Pascalis, V., \& Zimbardo, P. G. (2003). Testing Zimbardo's Stanford Time Perspective Inventory (STPI) - Short Form. Time \& Society, 12(2-3), 334-347. doi:10.1177/0961463X030122010

European Monitoring Centre for Drugs and Drug Addiction (EMCDDA) (2002). Handbook for surveys on drug use among the general population. EMCDDA Project CT.99.EP.08 B. Lisabon: EMCDDA.

Finucane, M. L., Slovic, P., Mertz, C. K., Flynn, J., \& Satterfield, T. A. (2000). Gender, race, and perceived risk: The 'white male' effect. Health, Risk \& Society, 2(2), 159-172. doi:10.1080/713670162

Flynn, J., Slovic, P., \& Mertz, C. K. (1994). Gender, race, and perception of environmental health risks. Risk Analysis, 14(6), 1101-1108. doi:10.1111/j.1539-6924.1994.tb00082.x

Gallup (2005). Who supports marijuana legalization? Retrieved January 19, 2013 from http://www.gallup.com/poll/19561/Who-SupportsMarijuana-Legalization.aspx

Gerrard, M., Gibbons, F. X., Reis-Bergan, M., \& Russell, D. W. (2000). Self-esteem, self-serving cognitions, and health risk behavior. Journal of Personality, 68(6), 1177-1201. doi:10.1111/1467-6494.00131

Gibbons, F. X., Eggleston, T. J., \& Benthin, A. C. (1997). Cognitive reactions to smoking relapse: The reciprocal relation between dissonance and self-esteem. Journal of Personality and Social Psychology, 72(1), 184-195. doi:10.1037//0022-3514.72.1.184

Glavak Tkalić, R., Miletić, G. M., Maričić, J., \& Wertag, A. (2012). Substance abuse among the general population in the Republic of Croatia. Zagreb: Institute of Social Sciences Ivo Pilar and Government of the Republic of Croatia - Office for combating drug abuse.

Gutteling, J. M., \& Wiegman, O. (1993). Gender-specific reactions to environmental hazards in the Netherlands. Sex Roles, 28(7-8), 433-447. doi:10.1007/BF00289606

Hamilton, J. M., Kives, K. D., Micevski, V., \& Grace, S. L. (2003). Time perspective and health-promoting behavior in a cardiac rehabilitation population. Behavioral Medicine, 28(4), 132-139. doi:10.1080/089 64280309596051

Harrison, J. A., Mullen, P. D., \& Green, L. W. (1992). A meta-analysis of studies of the Health Belief Model with adults. Health Education Research, 7(1), 107-116. doi:10.1093/her/7.1.107

Jenks, R. J. (1992). Attitudes, perceptions, and risk-taking behaviors of smokers, ex-smokers, and nonsmokers. Journal of Social Psychology, 132(5), 569-575. doi:10.1080/00224545.1992.9713895

Johnson, V. (1988). Adolescent alcohol and marijuana use: A longitudinal assessment of a social learning perspective. American Journal of Drug and Alcohol Abuse, 14(3), 419-439. doi:10.3109/00952998809001561 
DRUŠ. ISTRAŽ. ZAGREB GOD. 22 (2013), BR. 4 STR. 579-599

MARIČIĆ, J., SUČIĆ, I., ŠAKIĆ, V.: RISK PERCEPTION..
Kahle, L. R., \& Berman, J. J. (1979). Attitudes cause behavior: A crosslagged panel analysis. Journal of Personality and Social Psychology, 37(3), 315-321. doi:10.1037/0022-3514.37.3.315

Kauffman, S. E., Silver, P., \& Poulin, J. (1997). Gender differences in attitudes toward alcohol, tobacco, and other drugs. Social Work, 42(3), 231-241. doi:10.1093/sw/42.3.231

Keough, K. A., Zimbardo, P. G., \& Boyd, J. N. (1999). Who's smoking, drinking, and using drugs? Time perspective as a predictor of substance use. Basic \& Applied Social Psychology, 21(2), 149-164. doi:10. $1207 / 15324839951036498$

Kerr, W. C., Greenfield, T. K., Bond, J., Ye, Y., \& Rehm, J. (2007). Age-period-cohort influences on trends in past year marijuana use in the US from the 1984, 1990, 1995 and 2000 National alcohol surveys. Drug and Alcohol Dependence, 86(2-3), 132-138. doi:10.1016/j.drugalcdep. 2006.05.022

Kotchick, B. A., Shaffer, A., Forehand, R., \& Miller, K. (2001). Adolescent sexual risk behavior: A multi-system perspective. Clinical Psychology Review, 21(4), 493-519. doi:10.1016/S0272-7358(99)00070-7

Lejčková, P., \& Csémy, L. (2005). Risk perception and attitudes of young people towards drug use. Adiktologie, 5(1), 34-48.

Lundborg, P., \& Lindgren, B. (2002). Risk perceptions and alcohol consumption among young people. Journal of Risk and Uncertainty, 25(2), 165-183. doi:10.1023/A:1020695730192

Lynskey, M. T., Grant, J. D., Nelson, E. C., Bucholz, K. K., Madden, P. A. F., Statham, D. J., Martin, N. G., \& Heath, A. C. (2006). Novel approaches to phenotyping drug abuse. Addictive Behaviors, 31(6), 984-994. doi:10.1016/j.addbeh.2006.03.048

MacCoun, J., Kahan, R. J., Gillespie, J., \& Rhee, J. (1993). A content analysis of the drug legalization debate. Journal of Drug Issues, 23(4), 615-630.

Marcoux, B. C., \& Shope, J. T. (1997). Application of the Theory of planned behavior to adolescent use and misuse of alcohol. Health Education Research, 12(3), 323-331. doi:10.1093/her/12.3.323

Mazis, M. B., Morris, L. A., \& Swasy, J. L. (1991). An evaluation of the alcohol warning label: Initial survey results. Journal of Public Policy and Marketing, 10(1), 229-241.

Mravčík, V., Korčišová, B., Lejčková, P., Miovská, L., Škrdlantová, E., Petroš, O., Sklenář, V., \& Vopravil, J. (2005). Annual report: the Czech Republic - 2004 drug situation. Prague: Office of the Government of the Czech Republic.

Park, E. R., Ostroff, J. S., Rakowski, W., Gareen, I. F., Diefenbach, M. A., Feibelmann, S., \& Rigotti, N. A. (2009). Risk perceptions among participants undergoing lung cancer screening: Baseline results from the national lung screening trial. Annals of Behavioral Medicine, 37(3), 268-279. doi:10.1007/s12160-009-9112-9

Peretti-Watel, P. (2003). Neutralization theory and the denial of risk: Some evidence from cannabis use among French adolescents. British Journal of Sociology, 54(1), 21-42. doi:10.1080/0007131032000045888 
DRUŠ. ISTRAŽ. ZAGREB GOD. 22 (2013), BR. 4, STR. 579-599

MARIČIĆ, J., SUČIĆ, I., ŠAKIĆ, V.:

RISK PERCEPTION.
Ravert, R. D., Schwartz, S. J., Zamboanga, B. L., Kim, S. Y., Weisskirch, R. S., \& Bersamin, M. (2009). Sensation seeking and danger invulnerability: Paths to college student risk-taking. Personality and Individual Differences, 47(7), 763-768. doi:10.1016/j.paid.2009.06.017

Reyna, V. F., \& Lloyd, F. (2006). Physician decision making and cardiac risk: Effects of knowledge, risk perception, risk tolerance, and fuzzy processing. Journal of Experimental Psychology: Applied, 12(3), 179-195. doi:10.1037/1076-898X.12.3.179

Rienzi, B. M., McMillin, J. D., Dickson, C. L., Crauthers, D., McNeill, K. F., Pesina, M. D., \& Mann, E. (1996). Gender differences regarding peer influence and attitude toward substance abuse. Journal of Drug Education, 26(4), 339-347. doi:10.2190/52C7-5P6B-FPH2-K5AH

Roberts, S. C. M. (2012). Macro-level gender equality and alcohol consumption: A multi-level analysis across U.S. States. Social Science $\mathcal{E}$ Medicine, 75(1), 60-68. doi:10.1016/j.socscimed.2012.02.017

Room, R. (2005). Stigma, social inequality and alcohol and drug use. Drug and Alcohol Review, 24(2), 143-155. doi:10.1080/09595230500102434

Saieva, A. P. (2008). Marijuana legalization: Americans' attitudes over four decades. University of Central Florida, A thesis - Master of Science in the Department of Sociology in the College of Sciences at the University of Central Florida Orlando, Florida.

Sharma, M. (2011). Health belief model: Need for more utilization in alcohol and drug education. Journal of Alcohol and Drug Education, 55(1), 3-6.

Spigner, C., Hawkins, W., \& Loren, W. (1993). Gender differences in perception of risk associated with alcohol and drug use among college students. Women Health, 20(1), 87-97. doi:10.1300/J013v20n01_06

Stacy, A. W., Bentler, P. M., \& Flay, B. R. (1994). Attitudes and health behavior in diverse populations: Drunk driving, alcohol use, binge eating, marijuana use, and cigarette use. Health Psychology, 13(1), 73-85. doi:10.1037//0278-6133.13.1.73

Steptoe, A., Wardle, J., Cui, W., Bellisle, F., Zotti, A., Baranyai, R., \& Sanderman, R. (2002). Trends in smoking, diet, physical exercise, and attitudes toward health in European university students from 13 countries, 1990-2000. Preventive Medicine, 35(2), 97-104. doi:10.1006/ pmed.2002.1048

Sutton, S. R. (1999). How accurate are smokers' perceptions of risk? Health, Risk E Society, 1(2), 223-230. doi:10.1080/13698579908407020

Trevino, R. A., \& Richard, A. J. (2002). Attitudes towards drug legalization among drug users. American Journal of Drug Alcohol Abuse, 28(1), 91-108. doi:10.1081/ADA-120001283

Vugrinec, L., Jerković, D., Markelić, M., Markus, M., Ivandić Zimić, J., Mikulić, S., Vukičević, J., \& Andreić, J-L. (2011). 2011 Croatian Report on Drugs Situation to the EMCDDA. Zagreb: Office for Combating Drugs Abuse of the Government of the Republic of Croatia.

Weinstein, N. D. (1999). What does it mean to understand a risk? Evaluating risk comprehension. Journal of the National Cancer Institute Monographs, 25, 15-20. doi:10.1093/oxfordjournals.jncimonographs. a024192 
DRUŠ. ISTRAŽ. ZAGREB GOD. 22 (2013), BR. 4 STR. 579-599

MARIČIĆ, J., SUČIĆ, I., ŠAKIĆ, $\mathrm{V}$.

RISK PERCEPTION..
Weinstein, N. D. (2003). Exploring the links between risk perceptions and preventive health behaviour. In J. Suls, \& K. Wallston (Eds.), Social psychological foundations of health and illness (pp. 22-53). New York, NY: Blackwell. doi:10.1002/9780470753552.ch2

Zimbardo, P. G., \& Boyd, J. N. (1999). Putting time in perspective: A valid, reliable individual-differences metric. Journal of Personality and Social Psychology, 77(6), 1271-1288. doi:10.1037/0022-3514.77.6.1271

Zimbardo, P. G., Keough, K. A., \& Boyd, J. N. (1997). Present time perspective as a predictor of risky driving. Personality and Individual Differences, 23(6), 1007-1023. doi:10.1016/S0191-8869(97)00113-X

\section{Povezanost dobi, spola i uporabe sredstava ovisnosti s percepcijom rizika i stavovima prema uporabi i legalizaciji (i) legalnih sredstava ovisnosti}

Jelena MARIČIĆ, Ines SUČIĆ, Vlado ŠAKIĆ Institut društvenih znanosti Ivo Pilar, Zagreb

Cilj istraživanja bio je utvrditi odnos dobi, spola te uporabe duhana, alkohola i marihuane i različitih aspekata stavova prema uporabi (i)legalnih sredstava ovisnosti. Ispitivane su razlike u percepciji rizika i stavovima prema uporabi sredstava ovisnosti među skupinama aktivnih konzumenata, bivših konzumenata i nekonzumenata, a s obzirom na njihovu dob i spol. Sudionici općenito smatraju da je uporaba duhana/alkohola/marihuane povezana s umjerenim rizikom, a da je uporaba ekstazija/kokaina/ heroina povezana s visokim rizikom, te općenito ne podržavaju njihovu uporabu ni legalizaciju. Utvrđena je i pozitivna povezanost između uporabe sredstava ovisnosti, kao i između stavova o kriminalizaciiji droga, percepcije rizika povezanog s uporabom te neodobravanja uporabe (i) legalnih sredstava ovisnosti. Žene i stariji sudionici u pravilu manje konzumiraju (i)legalna sredstva ovisnosti, manje podržavaju legalizaciju marihuane i heroina te su skloniji neodobravanju uporabe sredstava ovisnosti i stavu da je ona rizična. Aktivni konzumenti bilo kojega sredstva ovisnosti u pravilu imaju najpermisivnije stavove u odnosu na bivše konzumente i nekonzumente. Utvrđeno je da uporaba alkohola i duhana ima najiači učinak na stavove najmlađih, a najslabiji na stavove najstarijih sudionika, što upućuje na potrebu dodatnog usmjeravanja intervencija prema mlađoj populaciii.

Ključne riječi: percepcija rizika, stavovi, duhan, konzumacija alkohola i marihuane, aktivni konzumenti, bivši konzumenti, nekonzumenti 